UNDERGRADUATE RESEARCH IN NATURAL AND CLINICAL SCIENCE AND TECHNOLOGY (URNCST) JOURNAL Read more URNCST Journal articles and submit your own today at: https://www.urncst.com

\title{
Vitamin D Status in Cow's Milk Protein Allergy
}

Sumitha Grace Pandiaraja, MB BCh BAO (Hons) [1]*, Ioana Maris, MD, PhD [2]

[1] University College Cork, College Road, Cork, T12 K8AF, Ireland

[2] Bon Secours Hospital Cork, Department of Paediatrics and Child Health, University

College Cork, College Road, Cork, T12 K8AF, Ireland

*Corresponding Author: 115106390@umail.ucc.ie

\section{Abstract}

Introduction: Cow's milk protein allergy (CMPA) affects $1.9-4.9 \%$ of children worldwide

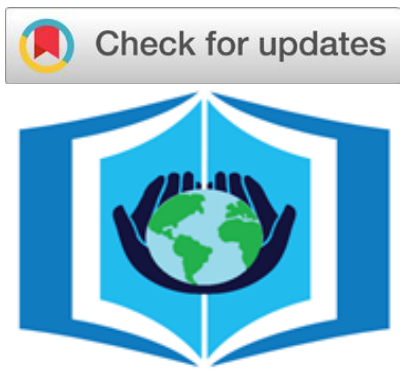

URNCST Journal

"Research in Earnest" and can be IgE-mediated or non-IgE mediated. Studies have highlighted the increased risk of inadequate vitamin D intake in children with CMPA on elimination diets, with potential effects on bone health, respiratory health and immune function. This study aims to investigate whether children with CMPA are at a higher risk of vitamin D insufficiency than their healthy counterparts.

Methods: This was an observational, cross-sectional study carried out at the specialist Paediatric Allergy Clinic, Bon Secours Hospital Cork and the Department of Paediatrics, Bon Secours Hospital Cork. 52 children with CMPA and 26 healthy controls, aged 6 to 24 months, were included. Exclusion criteria included known bone metabolism disorders, chronic renal and gastrointestinal disorders, and chronic infectious diseases. A retrospective chart review of children with CMPA was conducted to collect data on patient demographics, clinical presentation, and management. Serum 25(OH)D levels of children with CMPA $(n=18)$ and healthy controls $(n=26)$ were quantified and compared. Caregivers of children with CMPA were administered an online questionnaire to assess compliance to vitamin D supplementation.

Results: The serum 25(OH)D levels of children with CMPA were significantly lower than that of healthy controls (47.5 vs $62.5 \mathrm{nmol} / \mathrm{L}, \mathrm{p}=0.030)$. Among children with CMPA, children with IgE-mediated CMPA (p=0.041) and children with multiple concomitant IgE-mediated food allergies $(\mathrm{p}=0.011)$ had significantly lower serum $25(\mathrm{OH}) \mathrm{D}$ levels than their healthy counterparts. Among children with CMPA, breastfeeding status, reported vitamin D supplement use, age and gender were not significantly associated with serum $25(\mathrm{OH}) \mathrm{D}$ levels. The questionnaire revealed only $44.4 \%$ of caregivers to be fully adherent to vitamin D supplementation guidelines.

Conclusion: Children with CMPA are at higher risk of serum 25(OH)D insufficiency than healthy controls. Closer monitoring is required to ensure that vitamin D supplements are administered from birth to 12 months, at the recommended frequency.

Keywords: cow's milk protein allergy; vitamin D insufficiency; supplementation; children; infants

\section{Introduction}

\subsection{Cow's milk protein allergy}

Cow's milk protein allergy (CMPA) is an immunemediated food hypersensitivity that affects between $1.9 \%$ and $4.9 \%$ [1-2] of young children worldwide. CMPA can be IgE or non-IgE mediated. IgE-mediated CMPA presents predominantly with immediate symptoms such as vomiting, acute urticaria, angioedema and wheezing while non-IgE mediated CMPA tends to present with a delayed onset of diarrhoea, constipation, bloody stools and atopic dermatitis. The dietary elimination of cow's milk proteins (CMP) is key to CMPA management. In exclusively breastfed infants, mothers should consume a CMP-free diet with vitamin D supplements [1,3]. In non-breastfed children aged less than 24 months, a CMP-free diet and replacement with a hypoallergenic formula is recommended [2]. Most children, after 9 months of age, are suitable for home-based reintroduction of extensively heated, "baked milk", products to promote CMP-tolerance acquisition [1, 4]. At ages above
24 months, solid foods and liquids free of CMP are thought to provide a nutritionally adequate elimination diet [3].

\subsection{Vitamin D insufficiency/deficiency in CMPA}

Several paediatric research societies have highlighted a higher risk of vitamin D (serum $25(\mathrm{OH}) \mathrm{D}$ ) deficiency in CMPA and recommend supplementation for the duration of the CMP-elimination diet [5-6]. However, serum 25(OH)D concentrations that constitute deficiency in children remain contentious [7-9] (Appendix A). The Institute of Medicine's serum $25(\mathrm{OH}) \mathrm{D}$ classification [9], adopted in this study, considers levels $<30 \mathrm{nmol} / \mathrm{L}$ deficient and levels between 30 and $50 \mathrm{nmol} / \mathrm{L}$ insufficient (Table 2). In general, low serum $25(\mathrm{OH}) \mathrm{D}$ levels in children can arise from low dietary intake, inadequate sun exposure, lack of supplementation and maternal hypovitaminosis [10]. In early childhood, however, cow's milk consumption and vitamin D supplements (VDS) are thought to be the greatest determinants of serum $25(\mathrm{OH}) \mathrm{D}$ status [11]. Hence, the elimination of dairy is 
UNDERGRADUATE RESEARCH IN NATURAL AND CLINICAL SCIENCE AND TECHNOLOGY (URNCST) JOURNAL Read more URNCST Journal articles and submit your own today at: https://www.urncst.com

particularly likely to cause nutritional deficiencies in young children with CMPA [12]. Failure to correct low serum $25(\mathrm{OH}) \mathrm{D}$ levels with VDS and fortified formula can compromise bone health [13], respiratory health and immune system function [14] in this group. In fact, inappropriately managed CMPA has resulted in children developing rickets[15] and multiple bone fractures [16] in the past.

On the contrary, a growing body of evidence suggests inadequate serum $25(\mathrm{OH}) \mathrm{D}$ levels may cause food allergen sensitisation [17], particularly IgE-mediated CMPA [18]. Low serum $25(\mathrm{OH}) \mathrm{D}$ levels prevent differentiation of naive $\mathrm{T}$ lymphocytes into regulatory $\mathrm{T}$ cells (Treg), which typically act to suppress harmful allergic responses mediated by Th1 and Th2 cells [19]. Adequate serum 25(OH)D levels can increase Treg levels, and may even promote the acquisition of tolerance in CMPA [20-21].

\section{$\underline{3.3 \text { Recommendations for vitamin D supplementation }}$}

Despite guidelines emphasising the need for formal nutritional assessment [2, 5-6], children with CMPA are currently not recognised as a high-risk group for serum $25(\mathrm{OH}) \mathrm{D}$ insufficiency in Ireland, and do not require screening [22]. Generic supplementation protocols are thought to sufficiently support children with CMPA to achieve the recommended dietary allowance for vitamin D. The Irish Health Service Executive (HSE) recommends that all infants, both breastfed and formula-fed, receive a daily $5 \mu \mathrm{g}$ vitamin D supplement from birth to 12 months of age [23]. However, the rates of VDS use in children with CMPA and the efficacy of generic supplementation protocols in achieving serum $25(\mathrm{OH}) \mathrm{D}$ sufficiency in CMPA have not been established.

Hence, this study aims to investigate whether children with CMPA are at higher risk of serum 25(OH)D insufficiency than the general paediatric population, assess their use of vitamin D supplementation, and ultimately, identify areas for improvement in the nutritional management of CMPA.

\section{Methods}

\subsection{Study design}

This was an observational, cross-sectional study carried out in the specialist Paediatric Allergy Clinic and Department of Paediatrics, Bon Secours Hospital Cork from October 2018 to January 2020. The study consisted of a retrospective chart review of children with CMPA and a follow-up questionnaire on VDS use for caregivers.

\subsection{Study participants}

Children aged between 6 and 24 months attending the Paediatric Allergy Clinic with an established diagnosis of IgE-mediated or non-IgE mediated CMPA were included $(n=52)$. The diagnosis was based on a suggestive clinical history and confirmed to be: (i) IgE-mediated CMPA in the case of a positive skin-prick test and/or raised serum CMPspecific IgE level, or (ii) non-IgE mediated CMPA in the case of symptom resolution with CMP elimination and recurrence on reintroduction. Patients with no evidence of CMPA or other food allergies, who have had serum 25(OH)D levels quantified between 6 and 24 months of age, were eligible for inclusion as controls $(n=26)$. The exclusion criteria for both cases and controls were (i) age $<6$ months or $>24$ months, (ii) known bone metabolism disorders, (iii) renal or gastrointestinal disorders, and (iv) chronic infectious diseases.

\subsection{Study procedures}

A chart review of referral letters and clinic visit proformas, both written and electronic, of children with CMPA $(n=52)$ was undertaken to obtain information on demographic and clinical variables. For patients identified as cases, measurement of serum $25(\mathrm{OH}) \mathrm{D}$ levels was advised and values obtained. The serum $25(\mathrm{OH}) \mathrm{D}$ levels, age and gender of selected controls $(n=26)$ were obtained from the Bon Secours Hospital laboratory. Letters containing the URL of the online questionnaire were posted to study participants in February $(n=38)$ and December $2019(n=43)$.

\subsection{Study measures}

\subsubsection{Clinical and demographic data}

Data on variables (Table 1) associated with demographic characteristics, clinical presentation and clinical management of children with CMPA were obtained from chart review.

\subsubsection{Serum 25(OH)D quantification}

For the analysis of serum $25(\mathrm{OH}) \mathrm{D}$ levels, a blood sample was collected by a trained professional and analysed using accredited methods such as mass spectrometry or automated immunoassay in the Bon Secours Hospital Laboratory or a HSE laboratory. Serum 25(OH)D levels of 18 children with CMPA and 26 healthy controls were obtained. For the purpose of this study, the internationally recognised Institute of Medicine's vitamin D classification, which is most similar to the HSE laboratory testing guidelines, was chosen (Table 2).

\subsubsection{Assessment of vitamin D supplementation usage}

Frequency, duration and dose of VDS use were assessed via a short questionnaire (Appendix B). Full compliance was defined as daily usage of VDS, at the recommended dose of $5 \mu \mathrm{g}$, from birth to the time of study, for children under 12 months of age, or from birth to 12 months of age, for children between 12 to 24 months of age. Non-compliance was deemed to be a complete lack of VDS for the first year of life. The difference between reported rates of VDS use, documented by a paediatrician in the patient's chart, and actual rates of adherence, based on questionnaire responses, was investigated. Caregivers' knowledge surrounding serum $25(\mathrm{OH}) \mathrm{D}$ deficiency and the HSE VDS recommendations was assessed using true-false statements. 
UNDERGRADUATE RESEARCH IN NATURAL AND CLINICAL SCIENCE AND TECHNOLOGY (URNCST) JOURNAL Read more URNCST Journal articles and submit your own today at: https://www.urncst.com

\subsection{Data analysis}

Statistical analysis was performed using SPSS IBM version 25. Continuous variables were tested for normality using the Shapiro-Wilk test. Descriptive statistics were expressed as means with standard deviations for normally distributed data, and medians with interquartile ranges for skewed distributions. The independent t-test, nonparametric Mann-Whitney U test and Kruskal-Wallis test with post-hoc Bonferroni-correction were utilised to assess associations between CMPA and continuous variables, while Pearson's chi-squared test and Fisher's exact test were used to assess associations between CMPA and categorical variables. Cases with missing serum $25(\mathrm{OH}) \mathrm{D}$ levels were excluded from inferential statistical analysis. An exact binomial test was used to assess the difference between reported and actual compliance to VDS. For all tests, the significance level was set at 0.05 .

\begin{tabular}{|lll|}
\hline \multicolumn{2}{|l|}{ Table 1. Clinical and Demographic Variables } & \\
Demographic & Clinical Presentation & Clinical Management \\
Age & Type of CMPA & Type of hypoallergenic formula \\
Gender & Symptoms on allergen exposure & Breastfeeding status \\
Ethnicity & Concomitant IgE-mediated food allergies & Vitamin D supplement use \\
& Presence of eczema & Solid food intake \\
& Atopic family history & Home-based CMP reintroduction \\
& Skin-prick test results & Acquisition of tolerance \\
& CMP-specific serum-IgE & Dietitian referral \\
\hline
\end{tabular}

\begin{tabular}{|lll|}
\hline \multicolumn{2}{|l|}{$\begin{array}{l}\text { Table 2. Institute of Medicine Vitamin D Classification } \\
\text { Serum 25(OH)D level } \\
\text { Description }\end{array}$} & $\mathbf{n m o l} / \mathbf{L}$ \\
Deficiency & $<30$ & $\begin{array}{l}\text { Risk of deficiency; may lead to rickets in infants and } \\
\text { children }\end{array}$ \\
Insufficiency & $30-50$ & $\begin{array}{l}\text { Generally considered inadequate for bone and } \\
\text { overall health } \\
\text { Generally considered adequate for bone and overall } \\
\text { health }\end{array}$ \\
Sufficiency & $\geq 50$ & Health Status \\
\hline
\end{tabular}

\section{Results}

5.1 Review of CMPA presentation and management

The mean age of CMPA diagnosis was 9.13 months $(n=52) .73 .1 \% \quad(n=38)$ of children had non-IgE mediated CMPA and 26.9\% ( $n=14)$ had IgE-mediated CMPA. At the point of chart review, children with CMPA were older (median: 16 months, Q1: 14.00, Q3: 24.00) than controls (11 months, Q1: 8.25, Q3: 14.00). All children were of Caucasian ethnicity.

Gastrointestinal manifestations, such as vomiting and diarrhoea, were the most frequently reported $(76.9 \%, \mathrm{n}=40)$ presenting symptoms. Gastrointestinal manifestations were significantly more common in non-IgE mediated CMPA
( $86.7 \%$ vs $50.0 \%, \mathrm{p}=0.010$ ) while skin symptoms were more likely in IgE-mediated CMPA (92.9\% vs $23.7 \%$, p <0.001). Patients with IgE-mediated CMPA were significantly more likely than peers with non-IgE mediated CMPA to have concomitant IgE-mediated allergies $(71.4 \%$ vs $15.8 \%$, $\mathrm{p}<0.001)$, be breastfed $(71.4 \%$ vs $31.6 \%, \mathrm{p}=0.001)$, and have eczema ( $85.7 \%$ vs $55.3 \%, \mathrm{p}=0.043)$ (Table 3$)$.

At the time of study, all children had been started on complementary feeding with solids. Of the $92.3 \%$ of patients who were eligible for home-based CMP reintroduction, $45.8 \%(\mathrm{n}=22)$ demonstrated steady progress on the "iMAP Milk Ladder" while $6.3 \%(n=3)$ developed allergic reactions on attempting CMP reintroduction. 
UNDERGRADUATE RESEARCH IN NATURAL AND CLINICAL SCIENCE AND TECHNOLOGY (URNCST) JOURNAL Read more URNCST Journal articles and submit your own today at: https://www.urncst.com

\begin{tabular}{|c|c|c|c|c|c|}
\hline & $\begin{array}{l}\text { Non-IgE mediated } \\
\text { CMPA }(n=38)\end{array}$ & $\begin{array}{l}\text { IgE-mediated } \\
\text { CMPA }(n=14)\end{array}$ & $\begin{array}{l}\text { CMPA } \\
(n=52)\end{array}$ & $\begin{array}{c}\text { Controls } \\
(n=26)\end{array}$ & $p$-value \\
\hline & n (\%) & n (\%) & n (\%) & n (\%) & \\
\hline $\begin{array}{l}\text { Gender } \\
\text { Female } \\
\text { Male }\end{array}$ & $\begin{array}{l}19(50.0) \\
19(50.0)\end{array}$ & $\begin{array}{l}8(57.1) \\
6(42.9)\end{array}$ & $\begin{array}{l}27(51.9) \\
25(48.1)\end{array}$ & $\begin{array}{l}12(46.2) \\
14(53.8)\end{array}$ & $0.405^{1}$ \\
\hline $\begin{array}{l}\text { Age } \\
\leq 12 \text { months } \\
13-24 \text { months }\end{array}$ & $\begin{array}{l}20(52.6) \\
18(47.4)\end{array}$ & $\begin{array}{l}7(50.0) \\
7(50.0)\end{array}$ & $\begin{array}{l}27(51.9) \\
25(48.1)\end{array}$ & $\begin{array}{c}4(15.4) \\
22(84.6)\end{array}$ & $0.003^{1}$ \\
\hline $\begin{array}{l}\text { Skin symptoms } \\
\text { Urticaria }\end{array}$ & $9(23.7)$ & $13(92.9)$ & $22(42.3)$ & & $<0.001^{2}$ \\
\hline $\begin{array}{l}\text { Gastrointestinal symptoms } \\
\text { Vomiting } \\
\text { Diarrhoea } \\
\text { Constipation } \\
\text { Irritability } \\
\text { Bloating } \\
\text { Poor weight gain } \\
\text { PR bleeding }\end{array}$ & $\begin{array}{l}33(86.7) \\
13(34.2) \\
16(42.1) \\
10(26.3) \\
9(23.7) \\
4(10.5) \\
3(7.9) \\
3(7.9)\end{array}$ & $\begin{array}{l}7(50.0) \\
3(21.4) \\
1(7.1) \\
2(14.3) \\
0(0.0) \\
0(0.0) \\
1(7.1) \\
0(0.0)\end{array}$ & $\begin{array}{l}40(78.4) \\
16(30.8) \\
17(32.7) \\
12(23.1) \\
9(17.3) \\
4(7.7) \\
4(7.7) \\
3(5.8)\end{array}$ & & $0.010^{2}$ \\
\hline $\begin{array}{l}\text { Respiratory symptoms } \\
\text { Rhinitis } \\
\text { Wheeze }\end{array}$ & $\begin{array}{l}2(5.3) \\
1(2.6) \\
1(2.6)\end{array}$ & $\begin{array}{l}1(7.1) \\
0(0.0) \\
1(7.1)\end{array}$ & $\begin{array}{l}3(5.8) \\
1(1.9) \\
2(3.8)\end{array}$ & & $0.391^{2}$ \\
\hline $\begin{array}{l}\text { Concomitant food allergies } \\
\text { (IgE) }\end{array}$ & $6(15.8)$ & $10(71.4)$ & $16(30.7)$ & & $<0.001^{2}$ \\
\hline Eczema & $21(55.3)$ & $12(85.7)$ & 10 (19.6) & & $0.043^{2}$ \\
\hline $\begin{array}{l}\text { First-degree relative with } \\
\text { atopy }\end{array}$ & $18(47.4)$ & $6(42.9)$ & $24(46.2)$ & & $0.745^{2}$ \\
\hline \multicolumn{6}{|l|}{ Feeding patterns } \\
\hline Partial breastfeeding & $12(31.6)$ & $10(71.4)$ & $22(42.3)$ & & $0.001^{2}$ \\
\hline $\begin{array}{l}\text { Extensively hydrolyzed } \\
\text { formula }\end{array}$ & $13(34.2)$ & $2(14.3)$ & $15(28.8)$ & & \\
\hline Amino acid formula & $8(21.1)$ & $0(0.0)$ & $8(15.4)$ & & \\
\hline $\begin{array}{l}\text { Soy formula/plant-based } \\
\text { milk/goat milk }\end{array}$ & $6(15.8)$ & $1(7.1)$ & $7(13.5)$ & & \\
\hline
\end{tabular}

${ }^{1} p$ value from Pearson's chi-squared test comparing children with CMPA and healthy controls.

${ }^{2} p$ value from Pearson's chi-squared test/Fisher's exact test comparing children with IgE-mediated CMPA and nonIgE mediated CMPA.

5.2 Vitamin D status of children with CMPA compared to healthy controls

Serum 25(OH)D levels of 18 patients with CMPA and 26 healthy controls were obtained (Appendix D). The median serum $25(\mathrm{OH}) \mathrm{D}$ level of children with CMPA was significantly lower than that of healthy controls $(47.50 \mathrm{vs}$ $62.5 \mathrm{nmol} / \mathrm{L}, \mathrm{U}=143.5, \mathrm{p}=0.030, \mathrm{r}=0.10634$ ) (Figure 1).
There was also a higher frequency of serum $25(\mathrm{OH}) \mathrm{D}$ insufficiency observed in those with CMPA compared to controls (55.6\% vs 30.8\%, $\mathrm{p}=0.091$ ) (Figure 2). A similar pattern was observed when an alternative definition of serum 25(OH)D insufficiency $(<75 \mathrm{nmol} / \mathrm{L})$ [8] was utilised for analysis $(88.9 \%$ vs $61.6 \%, p=0.134)$ (Appendix A). 
UNDERGRADUATE RESEARCH IN NATURAL AND CLINICAL SCIENCE AND TECHNOLOGY (URNCST) JOURNAL
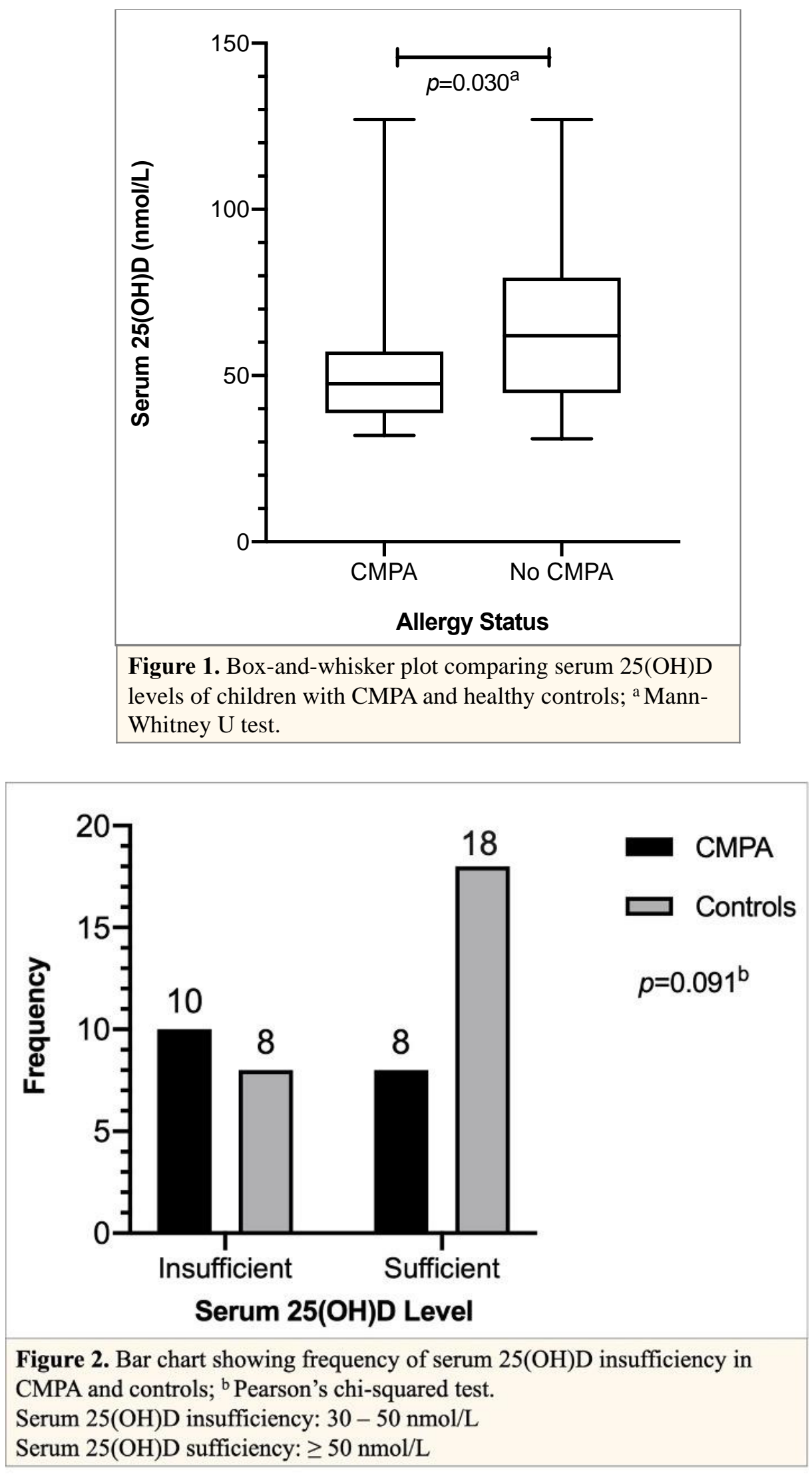
UNDERGRADUATE RESEARCH IN NATURAL AND CLINICAL SCIENCE AND TECHNOLOGY (URNCST) JOURNAL Read more URNCST Journal articles and submit your own today at: https://www.urncst.com

$\underline{5.3 \text { Factors affecting Vitamin D levels in children with CMPA }}$ Further sub-group analysis revealed that children with IgE-mediated CMPA ( $\mathrm{p}=0.041)$, and children with CMPA and multiple IgE-mediated allergies $(\mathrm{p}=0.011)$ had significantly lower serum $25(\mathrm{OH}) \mathrm{D}$ levels than their counterparts. A one-way Kruskal-Wallis test with post-hoc Bonferroni correction revealed that children with CMPA and concomitant IgE-mediated allergies had a significantly lower serum 25(OH)D level than controls (39.00 vs 62.00 $\mathrm{nmol} / \mathrm{L}, \mathrm{p}=0.004)$. However, no significant difference in serum $25(\mathrm{OH}) \mathrm{D}$ levels was detected between participants with CMPA alone and controls $(55.00$ vs $62.00 \mathrm{nmol} / \mathrm{L}$, $\mathrm{p}=1.0000^{*}$ ) (Figure 3). Interestingly, feeding patterns (breastfeeding vs hypoallergenic formula use), reported VDS use, age and gender were not significantly associated with serum 25(OH)D levels (Table 4).

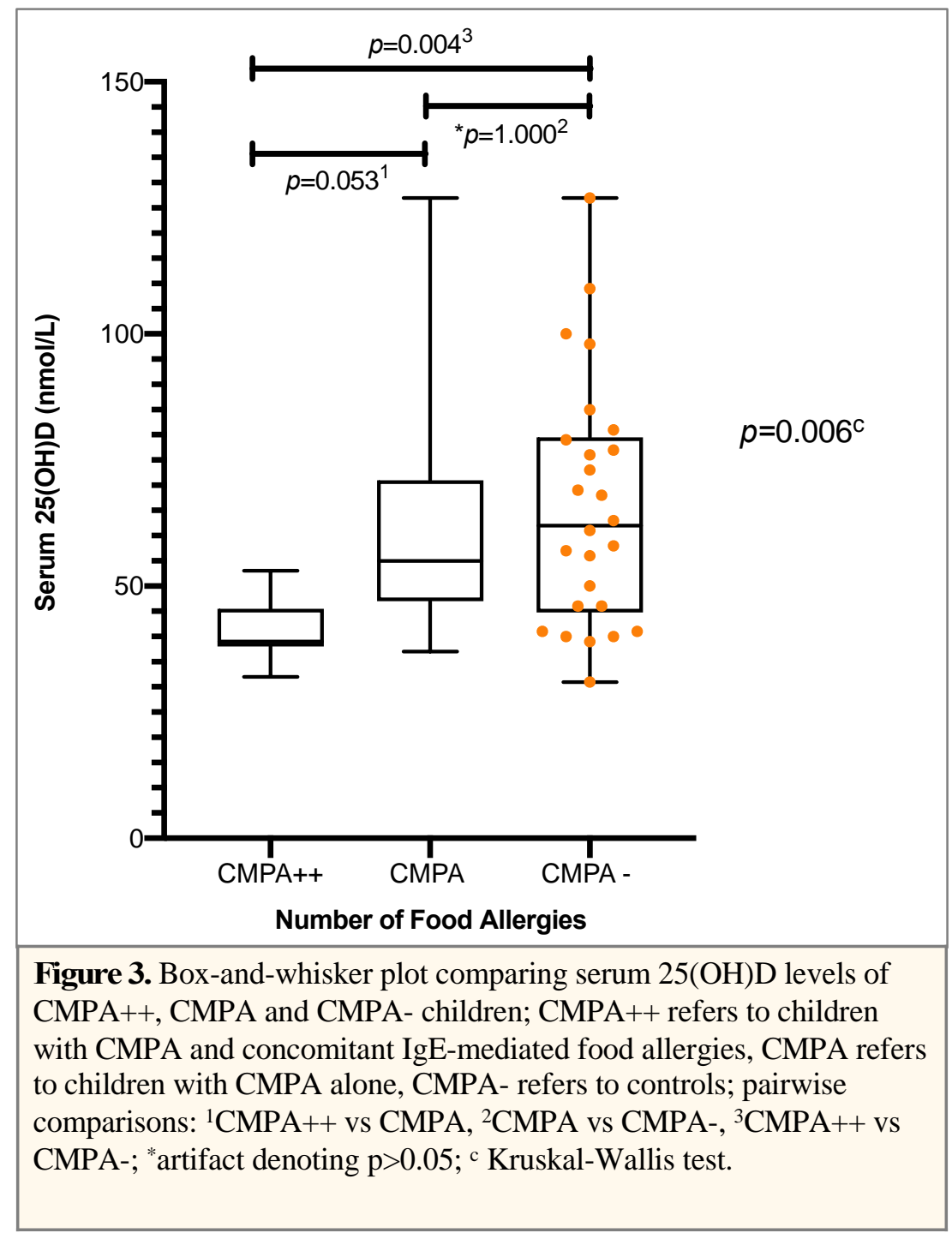


UNDERGRADUATE RESEARCH IN NATURAL AND CLINICAL SCIENCE AND TECHNOLOGY (URNCST) JOURNAL Read more URNCST Journal articles and submit your own today at: https://www.urncst.com

\begin{tabular}{|c|c|c|}
\hline & $\begin{array}{c}\text { Median }(\mathrm{IQR})^{1} / \text { Mean }_{( \pm \mathrm{SD})^{0}} \text { serum }^{25(\mathrm{OH}) D(\mathrm{nmol} / \mathrm{L})}\end{array}$ & $p$-value ${ }^{2}$ \\
\hline $\begin{array}{l}\text { Gender } \\
\text { Male }(n=7) \\
\text { Female }(n=11)\end{array}$ & $\begin{array}{l}39.00(38.00-57.00)^{1} \\
50.00(41.00-58.00)^{1}\end{array}$ & 0.318 \\
\hline $\begin{array}{l}\text { Age } \\
\qquad \leq 12 \text { months }(\mathrm{n}=11) \\
13-24 \text { months }(\mathrm{n}=7)\end{array}$ & $\begin{array}{l}44.00(37.00-48.00)^{1} \\
53.00(39.00-62.00)^{1}\end{array}$ & 0.063 \\
\hline $\begin{array}{l}\text { Feeding patterns } \\
\text { Breastfeeding }(n=11) \\
\text { Formula-feeding }(n=7)\end{array}$ & $\begin{array}{l}44.91( \pm 9.50)^{0} \\
66.71( \pm 32.96)^{0}\end{array}$ & $0.134^{3}$ \\
\hline $\begin{array}{l}\text { Type of CMPA } \\
\text { IgE-mediated }(\mathrm{n}=7) \\
\text { Non-IgE mediated }(\mathrm{n}=11)\end{array}$ & $\begin{array}{l}39.00(38.00-47.00)^{1} \\
53.00(44.00-62.00)^{1}\end{array}$ & 0.041 \\
\hline $\begin{array}{l}\text { Number of allergies } \\
\text { CMPA with concomitant allergies }(n=8) \\
\text { CMPA only }(n=10) \\
\text { No known food allergies }(n=26)\end{array}$ & $\begin{array}{l}39.00(38.00-45.50)^{1} \\
55.00(47.00-71.00)^{1} \\
62.00(44.75-79.50)^{1}\end{array}$ & $0.006^{4}$ \\
\hline $\begin{array}{l}\text { Reported VDS use } \\
\text { Compliant }(n=12) \\
\text { Partial/non-compliant }(n=6)\end{array}$ & $\begin{array}{l}49.00(39.50-57.75)^{1} \\
41.00(37.75-55.25)^{1}\end{array}$ & 0.291 \\
\hline
\end{tabular}

${ }^{1}$ Median (IQR); ${ }^{0}$ Mean ( \pm SD)

$p$ value obtained from: ${ }^{2}$ Mann-Whitney $\mathrm{U}$ test unless otherwise stated; ${ }^{3} \mathrm{t}$-test; ${ }^{4} \mathrm{Kruskal}-\mathrm{Wallis}$ test

\subsection{Rates of adherence to Vitamin D supplementation}

$80.8 \%(42 / 52)$ of children with CMPA reported full compliance to VDS at doctor's appointments. However, on closer scrutiny through the study questionnaire, only $44.4 \%$ (8/18) were using VDS at the correct duration and frequency (Table 5). An exact binomial test revealed a statistically significant difference in the rates of full compliance to VDS when reported in clinic compared to when assessed via the questionnaire $(83.3 \%$ vs $44.4 \%$, $\mathrm{p}=0.039)$. The main reasons for partial compliance were starting VDS late $(n=5,27.8 \%)$, frequent or rare use $(n=6$, $33.3 \%)$, and stopping supplementation prematurely $(n=2$, $11.1 \%$ ). Children fully compliant to VDS, based on questionnaire responses, were not more likely than partially compliant or non-compliant peers to have sufficient serum $25(\mathrm{OH}) \mathrm{D}$ levels $(100 \%$ vs $33.3 \%, \mathrm{p}=0.119)$. 
UNDERGRADUATE RESEARCH IN NATURAL AND CLINICAL SCIENCE AND TECHNOLOGY (URNCST) JOURNAL Read more URNCST Journal articles and submit your own today at: https://www.urncst.com

\begin{tabular}{|c|c|c|c|c|}
\hline & \multicolumn{3}{|c|}{ Questionnaire compliance } & \multirow{3}{*}{$\begin{array}{c}\text { Overall }(n=18) \\
n(\%)\end{array}$} \\
\hline & \multirow[b]{2}{*}{ Compliance } & \multicolumn{2}{|l|}{ n (\%) } & \\
\hline & & $\begin{array}{c}\text { Partial } \\
\text { compliance }\end{array}$ & Non-compliance & \\
\hline \multicolumn{5}{|l|}{ Reported compliance } \\
\hline Fully compliant & $7(38.9)$ & $8(44.4)$ & $0(0.0)$ & $15(83.3)$ \\
\hline Partially compliant & $1(5.6)$ & $1(5.6)$ & $0(0.0)$ & $2(11.1)$ \\
\hline Non-compliant & $0(0.0)$ & $0(0.0)$ & $1(5.6)$ & $1(5.6)$ \\
\hline \multicolumn{5}{|l|}{ Frequency } \\
\hline Daily & $8(44.4)$ & $3(16.7)$ & - & $11(61.1)$ \\
\hline Frequently (2-3/week) & - & $5(27.8)$ & - & $5(27.8)$ \\
\hline Rarely & - & $1(5.5)$ & - & $1(5.6)$ \\
\hline Never & - & - & $1(5.6)$ & $1(5.6)$ \\
\hline \multicolumn{5}{|l|}{ Duration } \\
\hline $0-12$ months & $8(44.4)$ & $2(11.1)$ & - & $10(55.6)$ \\
\hline Stopped prematurely & - & $2(11.1)$ & - & $2(11.1)$ \\
\hline Started late & - & $5(27.8)$ & - & $5(27.8)$ \\
\hline Not started & - & - & $1(5.6)$ & $1(5.6)$ \\
\hline \multicolumn{5}{|l|}{ Knowledge } \\
\hline Serum 25(OH)D & $17(94.4)$ & $1(5.6)$ & $0(0.0)$ & $17(94.4)$ \\
\hline $\begin{array}{l}\text { importance }^{1} \\
\text { HSE recommendations }\end{array}$ & $16(88.9)$ & $1(5.6)$ & $1(5.6)$ & $16(88.9)$ \\
\hline
\end{tabular}

${ }^{1}$ Answered True to " $\mathrm{C} 1$ : All children $\leq 12$ months old living in Ireland should receive a Vitamin D supplement"

${ }^{2}$ Answered True to "C2: Inadequate Vitamin D levels reduce bone health and can lead to rickets"

\section{Discussion}

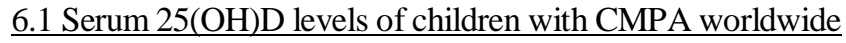

This study is one of the first studies in Ireland to investigate the serum $25(\mathrm{OH}) \mathrm{D}$ levels of children with CMPA. The mean serum $25(\mathrm{OH})$ D level of children aged $\leq$ 24 months with CMPA was found to be lower in this study $(53.4 \mathrm{nmol} / \mathrm{L}, \quad \mathrm{SD}=23.6)$ than levels reported internationally (range: 74 - $88.5 \mathrm{nmol} / \mathrm{L}$ ) [10, 21, 24, 25]. Considerable variation in the percentage of children with CMPA with "insufficient" serum 25(OH)D levels exists in current literature, ranging from $20.3 \%$ [10] to $80.0 \%$ [20]. However, heterogeneous definitions of serum $25(\mathrm{OH}) \mathrm{D}$ insufficiency in these studies hindered meaningful comparison. The lack of a consensus may reflect the current lack of understanding on the serum $25(\mathrm{OH}) \mathrm{D}$ level that exerts pathogenic effects on child health [26].

\subsection{Serum $25(\mathrm{OH}) \mathrm{D}$ levels of children with CMPA compared to controls}

Children with CMPA were found to have significantly lower serum $25(\mathrm{OH}) \mathrm{D}$ levels than healthy controls in our study (47.5 nmol/L vs $62.5 \mathrm{nmol} / \mathrm{L}, \mathrm{p}=0.031)$, reinforcing the widely reported tendency of food allergic children to have lower serum $25(\mathrm{OH}) \mathrm{D}$ levels [17-18, 27-29] than their peers. It must be noted that most of these studies [17-18, 27-29] had only include children with IgE-mediated
CMPA. This is potentially because of the growing interest in the scientific, in-vitro association [20-21] between low serum $25(\mathrm{OH}) \mathrm{D}$ levels, low Treg cell counts, and increased IgE sensitisation.

Of two recent studies including children $\leq 24$ months with both IgE and non-IgE mediated CMPA, Silva et. al. [10] corroborated our finding while Ercan et. al.[24] found no statistically significant difference in serum $25(\mathrm{OH}) \mathrm{D}$ levels between children with CMPA and controls. It is important to note that while none of the children in Silva et. al. were taking VDS, $100 \%$ of children and mothers in Ercan et. al. had been fully compliant to VDS in infancy and pregnancy respectively. Similar studies among older, pre-pubertal children [30-32] have reported no significant differences in serum 25(OH)D levels between CMPA and non-allergic groups. The varying findings of these existing studies highlight the relatively more important role that dietary vitamin D sources, including supplements, play in maintaining serum $25(\mathrm{OH}) \mathrm{D}$ levels in early childhood in comparison to later childhood and adolescence, when skin sunlight exposure becomes more determinant of [11] serum $25(\mathrm{OH}) \mathrm{D}$ levels. By including children with non-IgE mediated allergy, our study findings suggest that cow's milk exclusion can render children with either form of CMPA at risk of serum $25(\mathrm{OH}) \mathrm{D}$ insufficiency, underscoring their need for VDS. 
UNDERGRADUATE RESEARCH IN NATURAL AND CLINICAL SCIENCE AND TECHNOLOGY (URNCST) JOURNAL Read more URNCST Journal articles and submit your own today at: https://www.urnest.com

6.3 Factors affecting serum 25(OH)D levels among children with CMPA

6.3.1 Multiple concomitant IgE-mediated allergies

Children with CMPA and concomitant IgE-mediated allergies had significantly lower serum 25(OH)D concentrations than controls. This may seem intuitive since children with multiple food allergies have more restrictive elimination diets and are reportedly [33] at higher risk of insufficient nutritional intake. However, low serum $25(\mathrm{OH}) \mathrm{D}$ levels may, in fact, be predisposing children to multiple food allergies. Several studies have suggested that serum $25(\mathrm{OH}) \mathrm{D}$ insufficiency among children $\leq 24$ months renders them at higher risk of $\operatorname{IgE}$ sensitisation [28] and in particular, of developing multiple IgE-mediated food allergies [17-18,27]. This is further supported by our study findings, which suggested a significantly lower serum 25(OH)D level in IgE-mediated CMPA compared to nonIgE mediated CMPA, despite both groups being on similar CMP elimination diets.

\subsubsection{Breastfeeding status \& Vitamin D supplementation}

Previous studies have indicated a heightened risk of low serum 25(OH)D in patients with CMPA that are breastfed and not on fortified hypoallergenic formulas [10, 34-35]. Surprisingly, in our study, partially breastfeeding children did not have significantly lower serum 25(OH)D levels than peers on hypoallergenic formulas. Given that hypoallergenic formulas used by children in our study (e.g. Nutramigen, Neocate) [35-36] are expected to meet daily vitamin D intake requirements, our findings cast doubt on the efficacy of enteral vitamin D absorption in children with CMPA. In fact, the systemic inflammatory response mounted following allergen exposure may inhibit gastrointestinal absorption of fat-soluble vitamins, such as vitamin D [37-38]. This may be the reason that studies evaluating the effect of generic doses of enteral VDS in CMPA, including ours, have failed to find a correlation between supplementation and serum 25(OH)D levels in CMPA [39]. This calls for larger studies to investigate the appropriate dose, frequency and route of VDS administration for children with CMPA.

6.4 Vitamin D supplementation among children with CMPA in Ireland

The reported (80.8\%) and actual (44.4\%) rates of adherence to VDS among children with CMPA in Ireland fell within the range reported by previous studies [10, 39, 40] among children $\leq 24$ months of age. National recommendations seem to play a limited role in encouraging VDS use. For instance, a lower rate of VDS use was reported in an English study (0\%) [40] compared to a Norwegian study (86\%) [39], despite national recommendations in both countries. Instead, monitoring of adherence at health surveillance visits, and encouragement of supplementation independent of the mode of feeding have emerged as factors significantly promoting VDS adherence [41]. In fact, in our study, out of caregivers who provided a reason for stopping VDS prematurely $(\mathrm{n}=2)$ or after 12 months $(n=2), 75.0 \% \quad(n=3)$ cited confusion surrounding the need for VDS when their child stopped breastfeeding and/or started solid food intake. As such, it is important for healthcare professionals to emphasise that supplements be continued regardless of changes in feeding patterns, especially for children $\leq 12$ months of age.

\subsection{Limitations and future directions}

Serum 25(OH)D insufficiency is a complex and multifactorial problem. Our retrospective, cross-sectional study design and small sample size did not allow for confounding variables such as prenatal VDS, maternal hypovitaminosis, and sunlight exposure to be controlled for. The recruitment of controls on the basis of availability of serum $25(\mathrm{OH}) \mathrm{D}$ levels may also have introduced selection bias as clinical suspicion of insufficiency may have been the very reason for quantification of serum $25(\mathrm{OH}) \mathrm{D}$, resulting in levels unrepresentative of the healthy paediatric population. However, our strict exclusion criteria for renal and gastrointestinal diseases, and bone metabolism disorders should have mitigated this. Finally, participant bias may have affected the results of VDS questionnaires, with participants having a higher likelihood of recognising the importance of VDS than non-participants.

In the future, a prospective cohort study with repeated serum 25(OH)D level measurements at birth and at multiple time points i.e. pre-diagnosis, post-diagnosis and posttolerance acquisition can be useful to better understand the temporal relationship between low serum 25(OH)D levels and immune-mediated food hypersensitivities, especially CMPA. Furthermore, multi-centre studies can be conducted to achieve the sample size necessary to run an accurate multiple regression analysis to ascertain whether there exists an independent association between CMPA and serum 25(OH)D insufficiency. Finally, more scientific studies are essential to generate a more robust classification of serum 25(OH)D deficiency, insufficiency and adequacy. As long as the optimal serum $25(\mathrm{OH}) \mathrm{D}$ level needed to prevent negative health consequences remains nebulous, it is difficult to justify screening or craft special supplementation protocols for high-risk groups.

\section{Conclusions}

This study has shown that more than half of the children with CMPA had insufficient serum 25(OH)D levels. Despite high rates of VDS and fortified hypoallergenic formula use, children with CMPA on elimination diets appear to have significantly lower serum 25(OH)D levels than healthy controls. Notably, children with multiple concomitant allergies or the IgE-mediated form of CMPA may be particularly vulnerable to lower serum $25(\mathrm{OH}) \mathrm{D}$ levels, warranting closer monitoring. Maintenance on fortified hypoallergenic formulas, compliance to VDS and age $>12$ months were not significantly related to higher serum 25(OH)D levels in children with CMPA. Despite moderate 
UNDERGRADUATE RESEARCH IN NATURAL AND CLINICAL SCIENCE AND TECHNOLOGY (URNCST) JOURNAL Read more URNCST Journal articles and submit your own today at: https://www.urncst.com

rates of full compliance to VDS, caregivers exhibited a high degree of awareness of the value of vitamin $\mathrm{D}$ for health and the existence of the national HSE VDS recommendation. Thus, targeted patient counselling on the duration and frequency of supplement use is likely to be a promising method of improving VDS adherence and efficacy.

The findings of our study highlight that children with CMPA are at higher risk of serum $25(\mathrm{OH}) \mathrm{D}$ insufficiency, and act as an impetus for further research into optimising the nutritional management of CMPA, especially with respect to vitamin $\mathrm{D}$.

\section{List of Abbreviations}

CMPA: cow's milk protein allergy

CMP: cow's milk proteins

IgE: Immunoglobulin E

Serum 25(OH)D: Serum 25-hydroxyvitamin D / vitamin D

VDS: vitamin D supplement

Treg: regulatory $\mathrm{T}$ cells

HSE: Heatlh Service Executive

\section{Conflicts of Interest}

The author declares no conflict of interest.

\section{Ethics Approval and/or Participant Consent}

This research project was approved by the Clinical Research Ethics Committee (CREC) in July 2018 (Appendix C).

\section{Authors' Contributions}

SGP: designed study, collected and analysed data, drafted the manuscript

IM: designed study, collected data, reviewed manuscript

\section{Acknowledgements}

We wish to thank the staff at the UCC School of Medicine, members of the Clinical Research Ethics Committee, and members of the UCC statistical consulting service, without whom the completion of this project would not have been possible.

\section{Funding}

This study was not funded.

\section{References}

[1] Venter C, Brown T, Meyer R, Walsh J, Shah N, Nowak-Węgrzyn A, et al. Better recognition, diagnosis and management of non-IgE-mediated cow's milk allergy in infancy: iMAP-an international interpretation of the MAP (Milk Allergy in Primary Care) guideline. Clin Transl Allergy. 2017;7:26. Available from: https://doi.org/10.1186/s13601-017-0162-y.

[2] Fiocchi A, Brozek J, Schünemann H, Bahna SL, von Berg A, Beyer K, et al. World Allergy Organization (WAO) Diagnosis and Rationale for Action against Cow's Milk Allergy (DRACMA) Guidelines. World Allergy Organ J. 2010;3(4):57-161. Available from: https://doi.org/10.1097/WOX.0b013e3181defeb9.
[3] Koletzko S, Niggemann B, Arato A, Dias JA, Heuschkel R, Husby S, et al. Diagnostic approach and management of cow's-milk protein allergy in infants and children: ESPGHAN GI Committee practical guidelines. J Pediatr Gastroenterol Nutr. 2012;55(2):221-9. Available from: https://doi.org/ 10.1097/MPG.0b013e31825c9482.

[4] Ball HB, Luyt D. Home-based cow's milk reintroduction using a milk ladder in children less than 3 years old with IgE-mediated cow's milk allergy. Clin Exp Allergy. 2019;49(6):911-20. Available from: https://doi.org/10.1111/cea.13366.

[5] Giovannini M, D'Auria E, Caffarelli C, Verduci E, Barberi S, Indinnimeo L, et al. Nutritional management and follow up of infants and children with food allergy: Italian Society of Pediatric Nutrition/Italian Society of Pediatric Allergy and Immunology Task Force Position Statement. Italian Journal of Pediatrics. 2014;40(1):1-22. Available from: https://doi.org/10.1186/1824-7288-40-1.

[6] Dupont C, Chouraqui JP, de Boissieu D, Bocquet A, Bresson JL, Briend A, et al. Dietary treatment of cows' milk protein allergy in childhood: a commentary by the Committee on Nutrition of the French Society of Paediatrics. The British journal of nutrition. 2012;107(3):325-38. Available from: https://doi.org/ 10.1017/S0007114511004831.

[7] Lee JY, So TY, Thackray J. A review on vitamin d deficiency treatment in pediatric patients. J Pediatr Pharmacol Ther. 2013;18(4):277-91. Available from: https://doi.org/10.5863/1551-6776-18.4.277.

[8] Holick MF, Binkley NC, Bischoff-Ferrari HA, Gordon CM, Hanley DA, Heaney RP, et al. Evaluation, treatment, and prevention of vitamin D deficiency: an Endocrine Society clinical practice guideline. J Clin Endocrinol Metab. 2011;96(7):1911-30. Available from: https://doi.org/10.1210/ic.2011-0385.

[9] Medicine Io. Dietary Reference Intakes for Calcium and Vitamin D. Ross AC, Taylor CL, Yaktine AL, Del Valle HB, editors. Washington, DC: The National Academies Press; 2011. 1132 p.

[10] Silva CM, Silva SAD, Antunes MMC, Silva G, Sarinho ESC, Brandt KG. Do infants with cow's milk protein allergy have inadequate levels of vitamin D? J Pediatr (Rio J). 2017;93(6):632-8. Available from: https://doi.org/10.1016/j.jped.2017.01.006.

[11] Maguire JL, Birken CS, Khovratovich M, Degroot J, Carsley S, Thorpe KE, et al. Modifiable determinants of serum 25-hydroxyvitamin D status in early childhood: opportunities for prevention. JAMA Pediatr. 2013;167(3):230-5. Available from: https://doi.org/10.1001/2013.jamapediatrics.226.

[12] Le Louer B, Lemale J, Garcette K, Orzechowski C, Chalvon A, Girardet JP, et al. [Severe nutritional deficiencies in young infants with inappropriate plant milk consumption]. Archives de pediatrie : organe officiel de la Societe francaise de pediatrie. 2014; 
UNDERGRADUATE RESEARCH IN NATURAL AND CLINICAL SCIENCE AND TECHNOLOGY (URNCST) JOURNAL Read more URNCST Journal articles and submit your own today at: https://www.urncst.com

21(5):483-8. Available from: https://doi.org/10.1016/ j.arcped.2014.02.027.

[13] Laird E, Ward M, McSorley E, Strain JJ, Wallace J. Vitamin D and bone health: potential mechanisms. Nutrients. 2010;2(7):693-724. Available from: https://doi.org/10.3390/nu2070693.

[14] Searing DA, Leung DY. Vitamin D in atopic dermatitis, asthma and allergic diseases. Immunol Allergy Clin North Am. 2010;30(3):397-409. Available from: https://doi.org/10.1016/j.iac.2010.05.005.

[15] Levy Y, Davidovits M. Nutritional rickets in children with cows' milk allergy: calcium deficiency or vitamin D deficiency? Pediatric Allergy And Immunology: Official Publication Of The European Society Of Pediatric Allergy And Immunology. 2005;16(6):553Available from: https://doi.org/10.1111/j.1399-3038 2005.00270.x.

[16] Monti G, Libanore V, Marinaro L, Lala R, Miniero R, Savino F. Multiple bone fractures in an 8-year-old child with cow's milk allergy and inappropriate calcium supplementation. Annals of nutrition \& metabolism. 2007;51(3):228-31. Available from: https://doi.org/10.1159/000104142.

[17] Allen KJ, Koplin JJ, Ponsonby AL, Gurrin LC, Wake $\mathrm{M}$, Vuillermin $\mathrm{P}$, et al. Vitamin D insufficiency is associated with challenge-proven food allergy in infants. J Allergy Clin Immunol. 2013;131(4):1109-16, 16.e1-6. Available from: https://doi.org/10.1016/j.jaci 2013.01.017.

[18] Baek JH, Shin YH, Chung IH, Kim HJ, Yoo EG, Yoon $\mathrm{JW}$, et al. The link between serum vitamin D level, sensitization to food allergens, and the severity of atopic dermatitis in infancy. J Pediatr. 2014;165(4):849-54.e1. Available from: https://doi.org/10.1016/j.jpeds.2014 .06 .058 .

[19] Suaini NH, Zhang Y, Vuillermin PJ, Allen KJ, Harrison LC. Immune Modulation by Vitamin $\mathrm{D}$ and Its Relevance to Food Allergy. Nutrients. 2015;7(8):6088108. Available from: https://doi.org/10.3390/nu7085271.

[20] Mabrouk RR, Amer HaA, Soliman DA, Mohamed NA, El-Ghoneimy DH, Atef SM. Role of Vitamin D in the Induction of Regulatory $\mathrm{T}$ Cells Producing Interleukin 10 in Children with Cow Milk Allergy. Egyptian Journal of Hospital Medicine. 2016;65:454-67. Available from: https://doi.org/10.12816/0033753.

[21] Perezabad L, Lopez-Abente J, Alonso-Lebrero E, Seoane E, Pion M, Correa-Rocha R. The establishment of cow's milk protein allergy in infants is related with a deficit of regulatory $\mathrm{T}$ cells (Treg) and vitamin $\mathrm{D}$. Pediatric research. 2017;81(5):722-30. Available from: https://doi.org/10.1038/pr.2017.12.

[22] Gerard Boran JS. Laboratory Testing for Vitamin D Deficiency Ireland National Clinical Programme for Pathology; 2017. Contract No.: CSPD008/2018.

[23] Vitamin D supplementation for Infants - Information for Health Professionals Ireland: HSE 2010.
[24]Ercan N, Bostanci IB, Ozmen S, Tekindal MA. Is there an association between vitamin D levels and cow's milk protein allergy at infancy? Arch Argent Pediatr. 2019;117(5):306-13. Available from: https://doi.org/10.5546/aap.2019.eng.306.

[25] Sardecka I, Los-Rycharska E, Gawryjolek J, Toporowska-Kowalska E, Krogulska A. FOXP3 expression, vitamins $\mathrm{D}$ and $\mathrm{C}$ in the prediction of tolerance acquisition in infants with cow's milk allergy. J Investig Allergol Clin Immunol. 2019:0. Available from: https://doi.org/10.18176/jiaci.0422.

[26] Willits EK, Wang Z, Jin J, Patel B, Motosue M, Bhagia A, et al. Vitamin D and food allergies in children: A systematic review and meta-analysis. Allergy Asthma Proc. 2017;38(3):21-8. Available from: https://doi.org/ 10.2500/aap.2017.38.4043.

[27] Peroni DG, Piacentini GL, Cametti E, Chinellato I, Boner AL. Correlation between serum 25hydroxyvitamin D levels and severity of atopic dermatitis in children. $\mathrm{Br} \mathrm{J}$ Dermatol. 2011;164(5):1078-82. Available from: https://doi.org/ 10.1111/j.1365-2133.2010.10147.x.

[28] Sharief S, Jariwala S, Kumar J, Muntner P, Melamed ML. Vitamin D levels and food and environmental allergies in the United States: results from the National Health and Nutrition Examination Survey 2005-2006. J Allergy Clin Immunol. 2011;127(5):1195-202. Available from: https://doi.org/10.1016/j.jaci.2011.01.017.

[29] Alkazemi D, Albeajan M, Kubow S. Early Infant Feeding Practices as Possible Risk Factors for Immunoglobulin E-Mediated Food Allergies in Kuwait. Int J Pediatr. 2018;2018:1701903. Available from: https://doi.org/10.1155/2018/1701903.

[30] Ambroszkiewicz J, Rowicka G, Chełchowska M, Gajewska J, Strucińska M, Laskowska-Klita T. Serum concentrations of sclerostin and bone turnover markers in children with cow's milk allergy. Med Wieku Rozwoj. 2013;17(3):246-52. Available from: https://www.ncbi.nlm.nih.gov/pubmed/24296448.

[31] Rosendahl J, Fogelholm M, Pelkonen A, Mäkelä MJ, Mäkitie O, Erkkola M. A History of Cow's Milk Allergy Is Associated with Lower Vitamin D Status in Schoolchildren. Horm Res Paediatr. 2017;88(3-4):24450. Available from: https://doi.org/10.1159/000478779.

[32] Mailhot G, Perrone V, Alos N, Dubois J, Delvin E, Paradis L, et al. Cow's Milk Allergy and Bone Mineral Density in Prepubertal Children. Pediatrics. 2016;137(5). Available from: https://doi.org/10.1542/ peds.2015-1742.

[33] Sova C, Feuling MB, Baumler M, Gleason L, Tam JS, Zafra H, et al. Systematic review of nutrient intake and growth in children with multiple IgE-mediated food allergies. Nutrition in clinical practice : official publication of the American Society for Parenteral and Enteral Nutrition. 2013;28(6):669-75. Available from: https://doi.org/10.1177/0884533613505870. 
[34]Meyer R, De Koker C, Dziubak R, Skrapac AK, Godwin H, Reeve K, et al. A practical approach to vitamin and mineral supplementation in food allergic children. Clin Transl Allergy. 2015;5:11. Available from: https://doi.org/10.1186/s13601-015-0054-y.

[35] Meyer R, De Koker C, Dziubak R, Godwin H, Dominguez-Ortega G, Shah N. Dietary elimination of children with food protein induced gastrointestinal allergy - micronutrient adequacy with and without a hypoallergenic formula? Clin Transl Allergy. 2014;4(1):31. Available from: https://doi.org/10.1186/ 2045-7022-4-31.

[36]Foong RX, Meyer R, Dziubak R, Lozinsky AC, Godwin H, Reeve K, et al. Establishing the prevalence of low vitamin $\mathrm{D}$ in non-immunoglobulin-E mediated gastrointestinal food allergic children in a tertiary centre. World Allergy Organ J. 2017;10(1):4. Available from: https://doi.org/10.1186/s40413-016-0135-y.

[37] Ghashut RA, Talwar D, Kinsella J, Duncan A, McMillan DC. The effect of the systemic inflammatory response on plasma vitamin $25(\mathrm{OH}) \mathrm{D}$ concentrations adjusted for albumin. PloS one. 2014;9(3):e92614. Available from: https://doi.org/10.1371/journal.pone .0092614 .
[38] Valenta R, Hochwallner H, Linhart B, Pahr S. Food allergies: the basics. Gastroenterology. 2015;148(6): 1120-31 e4. Available from: https://doi.org/10.1053/ j.gastro.2015.02.006.

[39] Kvammen JA, Thomassen RA, Eskerud MB, Rugtveit J, Henriksen C. Micronutrient Status and Nutritional Intake in 0-2 Year Old Children Consuming A Cows' Milk Exclusion Diet. J Pediatr Gastroenterol Nutr. 2018. Available from: https://doi.org/10.1097/ MPG.0000000000001942.

[40] Maslin K, Oliver EM, Scally KS, Atkinson J, Foote K, Venter $\mathrm{C}$, et al. Nutritional adequacy of a cows' milk exclusion diet in infancy. Clin Transl Allergy. 2016;6:20. Available from: https://doi.org/10.1186/ s13601-016-0109-8.

[41] Uday S, Kongjonaj A, Aguiar M, Tulchinsky T, Hogler W. Variations in infant and childhood vitamin D supplementation programmes across Europe and factors influencing adherence. Endocr Connect. 2017;6(8):667-75. Available from: https://doi.org/ 10.1530/EC-17-0193.

\section{$\underline{\text { Appendix A }}$}

Table comparing the frequency of serum $25(\mathrm{OH}) \mathrm{D}$ sufficiency, insufficiency and deficiency between children with CMPA and healthy controls using 2 different classification systems: (i) Institute of Medicine Classification and (ii) Endocrine Society Classification.

\begin{tabular}{|c|c|c|c|}
\hline & $\begin{array}{c}\text { CMPA group } \\
(\mathbf{n m o l} / \mathrm{L})\end{array}$ & $\begin{array}{c}\text { Control group } \\
(\mathrm{nmol} / \mathrm{L})\end{array}$ & $p$-value \\
\hline & Median (IQR) & Median (IQR) & \\
\hline \multirow[t]{2}{*}{ Overall } & $\begin{array}{l}47.5 \\
(\mathrm{Q} 1: 38.75, \mathrm{Q} 3: \\
57.25)\end{array}$ & $\begin{array}{l}62.5 \\
(\mathrm{Q} 1: 44.75, \mathrm{Q} 3: \\
79.50)\end{array}$ & \multirow[t]{2}{*}{$0.031^{1}$} \\
\hline & n (\%) & n (\%) & \\
\hline $\begin{array}{l}\text { Institute of Medicine Classification } \\
\text { Serum } 25(\mathrm{OH}) \mathrm{D} \text { insufficiency }(30-50 \mathrm{nmol} / \mathrm{L}) \\
\text { Serum } 25(\mathrm{OH}) \mathrm{D} \text { sufficiency }(\geq 50 \mathrm{nmol} / \mathrm{L})\end{array}$ & $\begin{array}{l}10(55.6) \\
8(44.4)\end{array}$ & $\begin{array}{c}8(30.8) \\
18(69.2)\end{array}$ & $0.091^{2}$ \\
\hline $\begin{array}{l}\text { Endocrine Society Classification } \\
\text { Serum } 25(\mathrm{OH}) \mathrm{D} \text { deficiency }(<50 \mathrm{nmol} / \mathrm{L}) \\
\text { Serum } 25(\mathrm{OH}) \mathrm{D} \text { insufficiency }(50-75 \mathrm{nmol} / \mathrm{L}) \\
\text { Serum } 25(\mathrm{OH}) \mathrm{D} \text { sufficiency }(>75 \mathrm{nmol} / \mathrm{L})\end{array}$ & $\begin{array}{c}10(55.6) \\
6(33.3) \\
2(11.1)\end{array}$ & $\begin{array}{c}8(30.8) \\
8(30.8) \\
10(38.5)\end{array}$ & $0.134^{3}$ \\
\hline
\end{tabular}

${ }^{1} p$ value from Mann-Whitney $\mathrm{U}$ test; ${ }^{2} p$ value from Pearson's chi-squared test; ${ }^{3} p$ value from Fisher's exact test. 
UNDERGRADUATE RESEARCH IN NATURAL AND CLINICAL SCIENCE AND TECHNOLOGY (URNCST) JOURNAL

Read more URNCST Journal articles and submit your own today at: https://www.urncst.com

\section{$\underline{\text { Appendix B }}$}

Questionnaire on Vitamin D supplement use administered to caregivers of children with CMPA.

\section{Vitamin D Supplement Use in Ireland}

This questionnaire aims to assess your child's use of vitamin D supplements. Thank you for taking the time to fill out this questionnaire. It is expected to take less than 10 minutes of your time.

1. What is your child's date of birth?

\section{SECTION A}

2. Question A1: Are you currently giving your child a vitamin D supplement? Mark only one oval.

Yes

No

\section{If you answered "No" to Question A1, please move on to Section B. If not, please complete Questions A2, A3 and A4.}

3. Question A2: At what age (in months) did your child start taking a vitamin $D$ supplement?

4. Question A3: What is the dose of vitamin D supplement (in micrograms) that your child takes per day?

5. Question A4: How often do you give your child a vitamin D supplement? Mark only one oval.

Daily

Frequently (i.e. once in every $2-3$ days)

Once a week

Rarely

Other: 


\section{If you have filled in Section A completely, please skip Section B and move on to Section C.}

\section{SECTION B}

NOTE: Only answer questions in Section B if you HAVE NOT answered Questions A2, A3 and A4!

6. Question B1: Have you ever given your child a vitamin D supplement in the past? Mark only one oval.

Yes

No

7. Question B2: What is the dose of the vitamin D supplement (in micrograms) that your child took per day?

8. Question B3: At what age (in months) did you start giving your child a vitamin D supplement?

9. Question B4: How often did you give your child a vitamin D supplement? Mark only one oval.

Daily

Frequently (i.e. once every 2-3 days)

Once a week

Rarely

Other:

10. Question B5: How many months did your child take vitamin D supplements for? 
UNDERGRADUATE RESEARCH IN NATURAL AND CLINICAL SCIENCE AND TECHNOLOGY (URNCST) JOURNAL

Read more URNCST Journal articles and submit your own today at: https://www.urncst.com

11. Question B6: What was your reason for stopping vitamin D supplementation for your child?

\section{SECTION C}

These questions are meant to assess your understanding of the need for Vitamin $D$ supplementation. Please select either "True" or "False" for each of the statements below. All survey participants are required to complete questions $\mathrm{C} 1$ and $\mathrm{C} 2$.

12. Question C1: All children $\leq 12$ months old living in Ireland should receive a vitamin $D$ supplement.

Mark only one oval.
True
False

13. Question C2: Inadequate levels of vitamin D reduce bone health and can lead to Rickets.

Mark only one oval.
True
False 
UNDERGRADUATE RESEARCH IN NATURAL AND CLINICAL SCIENCE AND TECHNOLOGY (URNCST) JOURNAL Read more URNCST Journal articles and submit your own today at: https://www.urncst.com

\section{$\underline{\text { Appendix C }}$}

This project was approved by the Clinical Research Ethics Committee on 27/07/18.

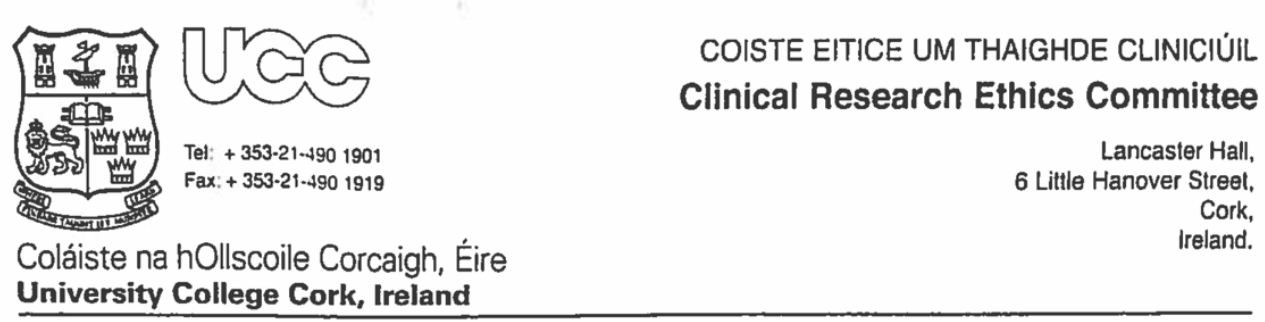

ECM 6 (ee) 14/08/18 Medical School Co-Ordinator: Dr Eileen Duggan

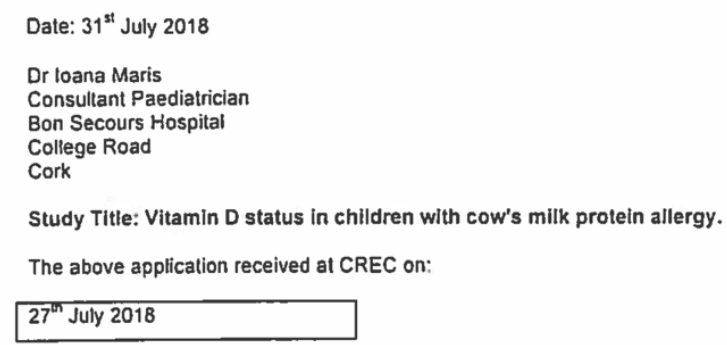

The co-investigator(s) involved in the project will be:

\begin{tabular}{|l|l|l|}
\hline Medical Student Name & Student Number & Other \\
\hline Sumitha Grace Pandiaraja & 115106390 & \\
\hline
\end{tabular}

Full approval is granted to carry out the above study.

Yours sincerely

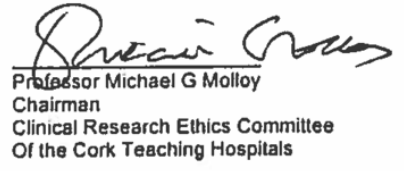

Clinical Research Ethics Commiltee 
UNDERGRADUATE RESEARCH IN NATURAL AND CLINICAL SCIENCE AND TECHNOLOGY (URNCST) JOURNAL Read more URNCST Journal articles and submit your own today at: https://www.urncst.com

\section{$\underline{\text { Appendix D }}$}

Flow chart representing numbers of children with CMPA (cases) at different stages of the study.

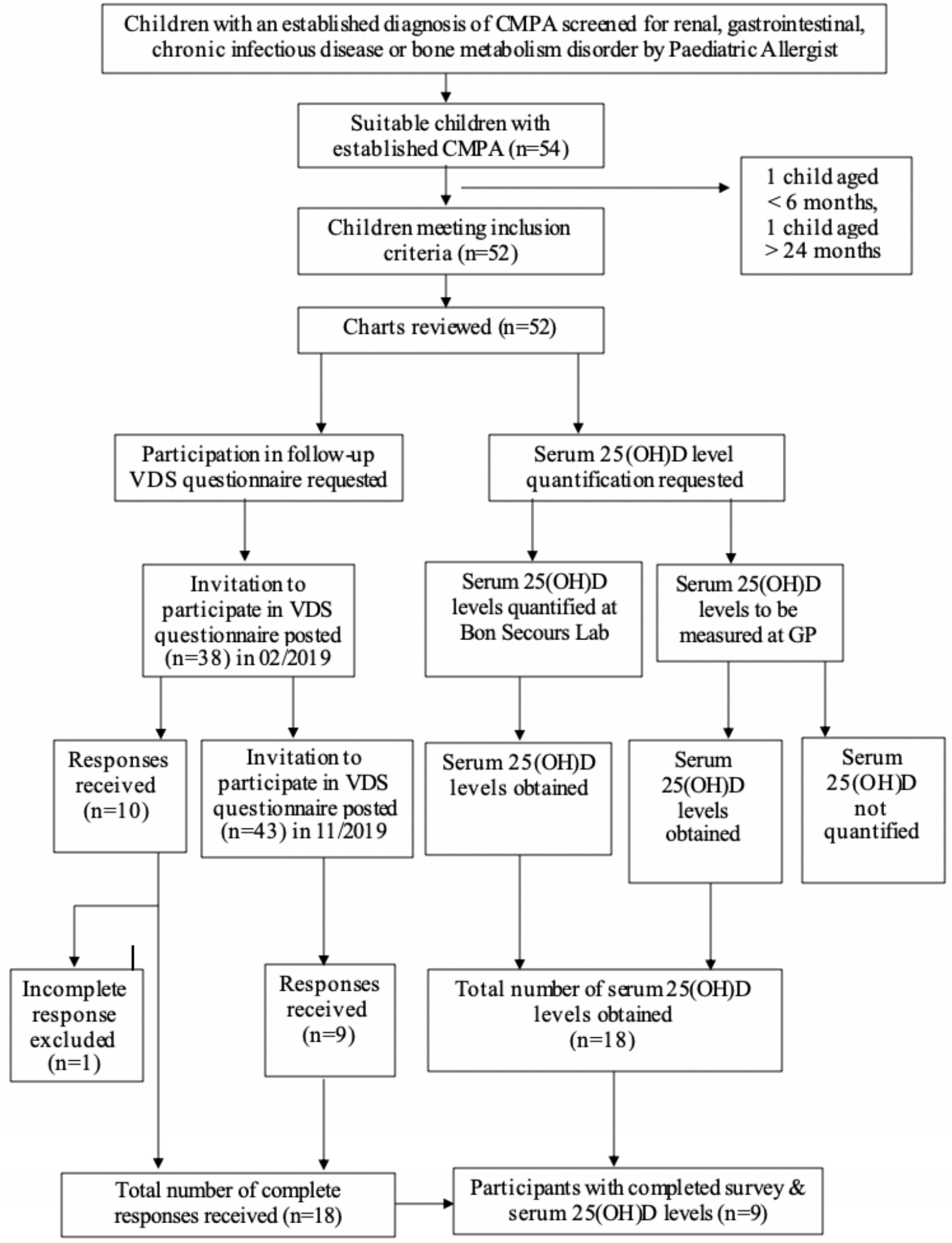


UNDERGRADUATE RESEARCH IN NATURAL AND CLINICAL SCIENCE AND TECHNOLOGY (URNCST) JOURNAL Read more URNCST Journal articles and submit your own today at: https://www.urncst.com

\section{$\underline{\text { Appendix E }}$}

Flow chart representing numbers of children with no evidence of CMPA (controls) at different stages of the study.

\begin{tabular}{|l|}
\hline $\begin{array}{c}\text { Serum 25(OH)D levels of children with no known CMPA obtained from Bon Secours } \\
\text { Laboratory }(\mathrm{n}=56)\end{array}$ \\
\begin{tabular}{|c|}
\hline Age, gender and allergy status reviewed $(\mathrm{n}=56)$ \\
\hline Children meeting inclusion and exclusion criteria included \\
as controls ( $\mathrm{n}=26)$
\end{tabular} \\
\hline
\end{tabular}

Article Information

Managing Editor: Jeremy Y. Ng

Peer Reviewers: Brad Currier, Jordan Donders

Article Dates: Received May 23 20; Accepted Aug 02 20; Published Nov 0220

\section{Citation}

Please cite this article as follows:

Pandiaraja SG, Maris I. Vitamin D status in cow's milk protein allergy. URNCST Journal. 2020 Nov 02: 4(10).

https://urncst.com/index.php/urncst/article/view/191

DOI Link: https://doi.org/10.26685/urncst.191

\section{Copyright}

(C) Sumitha Grace Pandiaraja, Ioana Maris. (2020). Published first in the Undergraduate Research in Natural and Clinical Science and Technology (URNCST) Journal. This is an open access article distributed under the terms of the Creative Commons Attribution License (https://creativecommons.org/licenses/by/4.0/), which permits unrestricted use, distribution, and reproduction in any medium, provided the original work, first published in the Undergraduate Research in Natural and Clinical Science and Technology (URNCST) Journal, is properly cited. The complete bibliographic information, a link to the original publication on http://www.urncst.com, as well as this copyright and license information must be included.
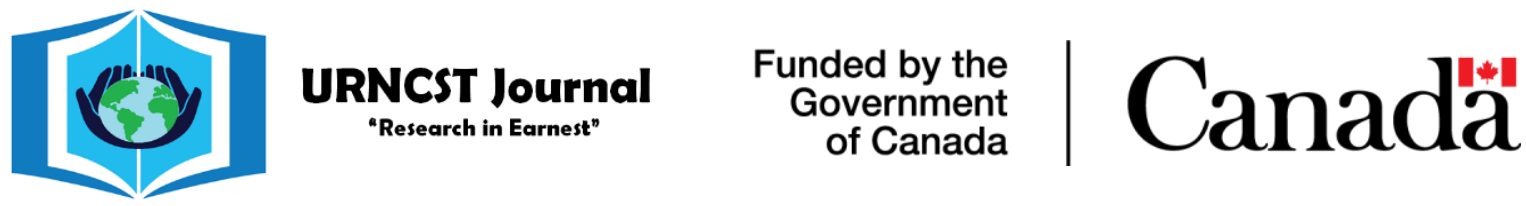

Do you research in earnest? Submit your next undergraduate research article to the URNCST Journal!

| Open Access | Peer-Reviewed | Rapid Turnaround Time | International |

| Broad and Multidisciplinary | Indexed | Innovative | Social Media Promoted |

Pre-submission inquiries? Send us an email at info@ urncst.com | Facebook, Twitter and LinkedIn: @ URNCST

Submit YOUR manuscript today at https://www.urncst.com! 